\title{
Determinants of foreign direct investment from OECD countries in Poland
}

\section{Andrzej Cieślik ${ }^{1}$}

Received: 29 December 2018 / Revised: 15 July 2019 / Accepted: 30 July 2019 /

Published online: 4 September 2019

(C) The Author(s) 2019

\begin{abstract}
In the last two decades, Poland became an important recipient of foreign direct investment most of which comes from the developed West European countries. This study uses panel data analysis to empirically examine the determinants of multinational activity of firms from the OECD member states in Poland during the period 1996-2015. The model's estimated empirical specification is based on the modified knowledge-capital model of the multinational enterprise that includes two types of capital: human and physical. Our empirical evidence points to the vertical motive as the primary reason for undertaking foreign direct investment in Poland by multinational firms based in the OECD member states.
\end{abstract}

Keywords Foreign direct investment - OECD member states · Panel data analysis · Poland $\cdot$ Relative factor endowments

JEL Classification F23 · P33

\section{Introduction}

Multinational enterprises (MNEs) are important actors in the ongoing process of globalization. During the last 25 years, foreign direct investment (FDI) made by MNEs grew more rapidly than both world trade and world GDP. FDI originates predominantly from developed countries which have been at the same time the major

Research reported in this paper was financed by the National Science Centre in Poland under the project no. 2015/19/B/HS4/03230 entitled 'Determinants of Foreign Direct Investment in Poland' and conducted by the author from 2016 through 2018 . The content is solely the responsibility of the author and does not necessarily represent the official views of the National Science Centre. The author wishes to thank Michael Ryan, the participants of 26th EBES conference in Prague and two anonymous reviewers for their comments and suggestions on the previous drafts of this paper.

Andrzej Cieślik

cieslik@wne.uw.edu.pl

1 Faculty of Economic Sciences, University of Warsaw, ul. Długa 44/50, 00-241 Warsaw, Poland 
recipients of FDI. According to UNCTAD (2018), the world inward FDI stock amounted to $\$ 31.5$ trillions of which $64.5 \%$ was located in the developed countries.

Poland which joined the Organisation for Economic Co-operation and Development (OECD) in 1998 and the European Union (EU) in 2004 has become an important target destination for inward FDI location in the last two decades. In 2017, the inward FDI stock invested in Poland since its economic transition in the early 1990 s amounted to $\$ 238.5$ billions which still accounts for less than $1 \%$ of the world inward FDI stock (NBP 2018). Nevertheless, compared to the pre-EU accession stock equal to $\$ 55.2$ billions in 2003 the inward FDI stock has increased more than fourfold and compared to the pre-OECD accession stock equal to only \$14.6 billions in 1997 the inward FDI stock increased more than 16-fold.

The majority of foreign capital stock invested in Poland in 2017 originated from the other OECD countries-\$227.6 billions (95.4\%), and mostly from the other EU member states - $\$ 220.0$ billions (92.3\%). In 2017 the top five source countries were the developed West European economies, respectively: the Netherlands ( $\$ 45.8$ billions), Germany ( $\$ 41.9$ billions), Luxembourg ( $\$ 33.2$ billions), France ( $\$ 21.5$ billions) and Spain ( $\$ 14.4$ billions). Most foreign capital in Poland was invested in the manufacturing industry $-\$ 73.8$ billions $(31 \%)$, finance and insurance $-\$ 48.8$ billions $(20.5 \%)$, and wholesale and retail-\$33.2 billions (13.9\%).

While numerous theoretical models try to shed light on FDI determinants, the main motives why firms internationalize production include: market access and cost cutting (Markusen 2013). On the one hand, MNEs are vehicles to overcome distance and lower costs of foreign markets access. Foreign direct investment undertaken to serve local markets is often called horizontal FDI. It refers to producing abroad roughly the same goods and services as in the home country. On the other hand, firms internationalize production in order to acquire inputs at a lower cost. Foreign direct investment aiming at cost reductions is called vertical FDI. It involves fragmenting production processes and locating various stages in different countries where the factors used intensively in particular stages are relatively cheap. These two alternative reasons have different empirical implications.

As FDI in Poland originates predominantly from the OECD countries the main goal of this paper is to validate the predictions of competing theoretical models and identify the main determinants of inward FDI in Poland using bilateral panel dataset on FDI stock from the OECD member states covering the period 1996-2015. The estimated specification of the empirical model is based on the modified knowledge-capital model of the multinational enterprise that combines the horizontal and vertical reasons for FDI and includes two types of capital: human and physical. Moreover, in our study in addition to the full sample results, also the empirical results obtained separately for the pre-EU and the post-EU accession sub-periods are reported.

The paper is structured as follows. The next section surveys the relevant MNE literature and discusses the empirical implications of competing theoretical frameworks. Then, definitions, data sources and the empirical methodology are described. Finally, we present and discuss our estimation results. The paper concludes with final remarks, policy guidelines and directions for future studies. 


\section{Literature review}

To explain the phenomenon of international production, a large number of theoretical models were developed. Historically, the first strand focused on explaining FDI between similar countries. This strand in the literature was initiated by the early models of horizontal FDI elaborated by Krugman (1983) and Markusen (1984). Their models were later extended, inter alia, by Horstmann and Markusen (1987), Brainard (1993a), Markusen and Venables (1998, 2000), Helpman et al. (2004), Sinha (2010), Collie (2011), and more recently by Cieślik and Ryan (2012) and Cieślik (2013, 2015a, b, 2016, 2018). The second strand that focused on explaining FDI between developed and developing economies was initiated by Helpman (1984) and Helpman and Krugman (1985) who proposed the early models of vertical FDI. These models were later extended by, inter alia, Zhang and Markusen (1999), Markusen and Venables (2000) and Markusen (2002).

For many years, horizontal and vertical models of FDI were treated as two different literature strands. The next step in the FDI theory development was aimed at embedding horizontal and vertical components into one unified framework. This was finally achieved by Markusen (2002) who proposed the knowledge capital (KC) model in which firms could choose between exporting, horizontal FDI and vertical FDI. His model predicts that exporting is favored by national firms when trade costs are low and countries are similar in terms of their economic size and relative factor endowments. On the other hand, when trade costs are high and countries are similar in terms of their economic size and relative factor endowments horizontal FDI is a preferred foreign market entry strategy. Finally, vertical FDI takes place when countries are similar in terms of their size but dissimilar in relative factor endowments and trade costs are not too high.

In the following years, the $\mathrm{KC}$ model has been extended in many directions. These extensions include, inter alia, studies by Bergstrand and Egger (2007, 2013), Markusen and Strand (2009), Markusen and Stähler (2011), and Chen et al. (2012). The most important recent extension of the $\mathrm{KC}$ model is the incorporation of physical capital in addition to human capital. This allows a direct comparison of the $\mathrm{KC}$ model with the earlier models of horizontal and vertical FDI in which differences in relative factor endowments were determined only by physical capital to labor ratios.

Formal empirical studies that attempted to validate the predictions of the aforementioned theoretical models did not start until the early 1990s. These studies were initiated by Brainard (1993b, 1997) who tested predictions of competing models for American multinationals. She found that the majority of American MNEs were integrated horizontally, and not vertically. However, Carr et al. (2001) estimated specifications directly derived from the $\mathrm{KC}$ model and found that US MNEs were integrated not only horizontally but also vertically. Further empirical support for vertically-integrated MNEs was provided by Braconier et al. (2005) and Davies (2008).

The empirical determinants of inward FDI into Central and East European countries jointly have already been studied by a number of authors including, inter alia, Lansbury et al. (1996), Brenton et al. (1999), Benacek et al. (2000), Resmini (2000), Garibaldi et al. (2001), Bevan and Estrin (2004), Carstensen and Toubal (2004), 
Cieślik and Ryan (2004), Baniak et al. (2005), Gorbunova et al. (2012), and more recently also Wach and Wojciechowski (2016). The empirical studies for individual CEECs are more scarce. In particular, determinants of MNE activity in Poland were studied by Torrisi et al. (2009) and more recently by Cieślik (2017, 2019a, b).

However, with the exception of the recent studies by Cieślik (2017, 2019a, b), who used the number of firms with foreign capital participation as a proxy for the extent of MNE activity, the majority of previous studies made no attempts to test empirically the predictions derived directly from the NTMNE and differentiate between competing theoretical models. Hence, in contrast to the previous studies for Poland that used the number of firms with foreign capital participation as a dependent variable in this study, we use the actual data on the foreign direct investment position collected from the annual reports of the National Bank of Poland as a measure of inward FDI. Therefore, subsequent research on FDI motives using the alternative measure of foreign involvement would be definitely of interest as it would complement and revisit the already existing evidence.

\subsection{Data sources and empirical methodology}

The literature review provided in the previous section shows how foreign direct investment can be related to individual country characteristics. Country characteristics that affect the amount of FDI between countries in pure horizontal and vertical models appear also in the hybrid $\mathrm{KC}$ model. Hence, horizontal and vertical models can be treated as two special cases of the KC model and estimated using panel data for inward FDI in Poland originating from the OECD countries over the period 1996-2015. However, the expected impacts of country characteristics may differ across the models. Therefore, verifying which reasons for international production explain FDI can be achieved by looking at the signs and significance of estimated coefficients on the explanatory variables.

In particular, differences in the economic size and in relative factor endowments between Poland and the OECD member countries are the key explanatory variables that allow differentiating between the competing theoretical models. According to the pure horizontal and the $\mathrm{KC}$ models, there should be a negative relationship between differences in the country size and the amount of inward FDI in the host country. However, according to the pure vertical model, differences in the country size should not play any role. Hence, the negative and statistically significant coefficient on this variable can be expected if the market access motive is important and not significant otherwise.

The differences in the relative country size are measured using the squared difference in output-side real GDPs between the OECD source country and Poland (GDPDIFF). GDPs are expressed at chained PPPs and in constant 2011 US dollars. The GDP data come from the PennWorld Table (PWT) 9.0.

Moreover, according to the pure horizontal model, FDI in the host country should decrease with increased differences in relative factor endowments while the pure vertical and the $\mathrm{KC}$ models predict an opposite relationship. Hence, the estimated coefficient on the measures of differences in relative factor endowments variable should be negative and statistically significant if the market access motive is more 
important than the production cost motive and positive and statistically significant otherwise.

The differences in relative factor endowments between Poland and OECD partner countries are measured using differences in both human and physical capital per worker. The differences in human capital endowments (H-DIFF) are calculated using the human capital index, based on the years of schooling and returns to education. The differences in physical capital endowments (K-DIFF) are calculated using the capital stock expressed in PPPs in constant 2011 US dollars and the number of people employed. The data necessary to calculate differences in relative factor endowments also come from the PennWorld Table (PWT) 9.0.

In addition to the measures of differences in relative country size and in factor endowments that constitute a part of our identification strategy, we also need to control for the potential effects of some other factors. In particular, we control for the sum of Poland's and the source country's GDP (GDP-SUM). All three approaches, i.e. the pure horizontal, the pure vertical and the hybrid $\mathrm{KC}$ model, predict that the joint economic size of the country-pair should be positively related to the amount of inward FDI in the target country. Hence, a positive sign of the parameter on the GDP-SUM variable should be expected. In order to calculate the GDP-SUM variable we use the GDP data employed previously to calculate differences in relative country size. In order to avoid a potential endogeneity problem, absolute and relative country size variables as well as the differences in factor proportions are one period lagged.

Moreover, in order to control for the effects of distance related costs, we include physical geographic distance (DISTANCE). The theory does not provide clear predictions concerning the effects of various types of distance on FDI in the host country, however, previous empirical studies suggest a negative effect. The physical geographic distance is measured "as the crow flies" distance between the capitals of the OECD member states and the capital city of Poland (Warsaw) and it is expressed in kilometers. This distance data is available from the online distance calculator.

Finally, in order to find proxy for the obstacles to international trade and FDI, trade and investment freedom indices Poland and its investment partner countries $\left(\mathrm{TC}_{\text {parent }}, \mathrm{TC}_{\text {Poland }}, \mathrm{IC}_{\text {Poland }}\right)$ are included. IC stands for investment cost and $\mathrm{TC}$ stands for trade cost. These indices are compiled by the Heritage Foundation. The trade freedom index measures freedom from sizeable numbers and burdens of tariffs and non-tariff barriers to imports and exports of a country, while the investment freedom index measures freedom from restrictions on the movement and use of investment capital, regardless of activity, within and across the country's borders. ${ }^{1}$

\footnotetext{
1 The investment freedom was used only for Poland as the empirical study is related to one-way inward FDI only, i.e. from the source country to Poland and not the other way round. In contrast, trade freedom indices were used for both the source country and Poland as in the case of vertical FDI which is related to international fragmentation of production we should expect a negative relationship between trade costs for both countries as they hinder the movement of intermediate inputs and final goods across countries. However, in the case of horizontal FDI, only the trade freedom index for the host country should matter. In particular, the higher trade cost in Poland should encourage FDI while the trade cost in the source country should not play any role.
} 
The countries are scored $0-100$, with 0 being the least free and 100 the most free. The higher values of these indexes are associated with more trade and investment freedom. A score of 100 signifies an economic environment or a set of policies that is most conducive to economic freedom.

Moreover, in addition to investment freedom index, the measure of control of corruption index (CORRUPTION) is included to proxy for investment environment in the host country. It has been argued in the previous literature that corruption negatively affects the stock of international investment in the host country (Cieślik and Goczek 2018). The control of corruption index is obtained from the Worldwide Governance Indicators (WGI) database compiled by the World Bank. Similar to the Heritage Foundation indices, the measure of corruption also ranges from 0 to 100 with 0 being the least corrupt and 100 the most corrupt.

The definitions of explanatory variables and their summary statistics are summarized in Table 4 in "Appendix" while the calculated values of the pairwise correlations between the explanatory variables used in the empirical study are reported in Table 5 in the "Appendix". These results show that the explanatory variables are not strongly correlated with each other with exception of the correlation between the investment freedom index and the level of corruption where correlation exceeds 0.80 .

Inward FDI in Poland is measured using the data on the foreign direct investment position collected from the annual reports of the National Bank of Poland (NBP) (2003-2018). The foreign direct investment position is defined as the net sum of equity and debt instruments and the equity constitutes its major component. The first NBP report on FDI that was published in 2003 (National Bank of Poland (NBP) 2003-2018) includes also the data for earlier years starting from 1996. Therefore, the starting year of our sample is 1996 which is determined by data availability. Although FDI data is available for more recent years the last year of our sample is 2015 which is related to the data availability for our explanatory variables obtained from the PennWorld Table 9.0. Our sample embraces OECD countries during the period 1996-2015 which yields a panel of 680 observations. $^{2}$

The postulated theoretical relationships are estimated using the standard techniques of panel data econometrics including fixed and random effects estimators. The theoretical models discussed in the previous section are deterministic models that may not always fit the data for each country-pair in each year. Therefore, in order to control for the unobserved individual country-pair characteristics that are invariant over time we employ the fixed effects estimator. As a robustness test, we use the random effects estimator. In addition, in order to control for business cycle and policy changes such, as joining the EU, individual time effects are included.

The estimating equation in the generalized form is as follows:

\footnotetext{
2 In the last year of our sample-2015 the total inward FDI stock in Poland amounted to $\$ 185.9$ billion. The top three source countries among the OECD countries in 2015 were, respectively, the Netherlands with $\$ 34.5$ billion, Germany with $\$ 28.1$ billion and Luxembourg with $\$ 24.2$ billion.
} 


$$
\begin{aligned}
\ln F D I_{i j t} & =\alpha_{0}+\alpha_{1} \ln \left(Y_{i t}+Y_{j t}\right)+\alpha_{2} \ln \left(Y_{i t}-Y_{j t}\right)^{2}+ \\
& +\alpha_{3} \ln \left|K_{i t} / L_{i t}-K_{j t} / L_{j t}\right|+\alpha_{4} \ln \left|H_{i t} / L_{i t}-H_{j t} / L_{j t}\right| \\
& +\alpha_{5} \ln \operatorname{DISTANCE}_{i j}+\alpha_{6} I C_{i t}+\alpha_{7} T C_{i t}+\alpha_{8} T C_{j t}+\alpha_{9} \text { CORRUPTION }_{i t} \\
& +v_{i j}+u_{t}+\varepsilon_{i j t}
\end{aligned}
$$

where: FDI $_{\mathrm{ijt}}$ is bilateral inward FDI stock from country $i$ in country $j$ in year $t, \mathrm{Y}_{\mathrm{it}}$ and $Y_{j t}$ are respectively GDPs of country $i$ and country $j$ in year $t, K_{i t} / L_{i t}$ and $K_{j t} / L_{j t}$ are respectively the ratios of physical capital to workers in country $i$ and country $j$ in year $\mathrm{t}, \mathrm{H}_{\mathrm{it}} / \mathrm{L}_{\mathrm{it}}$ and $\mathrm{H}_{\mathrm{jl}} / \mathrm{L}_{\mathrm{jt}}$ are respectively the amounts of human capital per worker in country $i$ and country $j$ in year $t$, DISTANCE $E_{i j}$ is a variable measuring the geographical distance between the capitals of country $i$ and country $j, \mathrm{IC}_{\mathrm{it}}$ is a variable measuring the investment cost in country $i$ in year $t, \mathrm{TC}_{\mathrm{it}}$ is a variable measuring the trade cost in country $\mathrm{i}$ in year $\mathrm{t}, \mathrm{TC}_{\mathrm{jt}}$ is a variable measuring the investment cost in country $\mathrm{j}$ in year $\mathrm{t}$, CORRUPTION $\mathrm{it}_{\mathrm{it}}$ is a variable measuring the level of corruption in country $i$ in year $t, v_{i j}$ is the individual country-pair specific effect that may be fixed or random, while $\varepsilon_{\mathrm{ijt}}$ is the error term, for $\mathrm{i}=$ Poland, $\mathrm{j}=1, \ldots, 34$ investment partners of Poland from the OECD, $\mathrm{t}=1996, \ldots, 2015$, and $\alpha$ 's are the parameters to be estimated.

\subsection{Empirical results}

In this section, we present and discuss the empirical results. The estimation results for the full sample are shown in Table 1. In Table 2, we report estimation results obtained for the subsample limited to the pre-accession period 1996-2004. Finally, in Table 3 the results obtained for the subsample limited to the post-accession years 2004-2015 are reported.

The benchmark estimation results obtained via the fixed effects estimator without controlling for individual time effects are presented in column (1) of Table 1. It turns out that the majority of the estimated coefficients on our explanatory variables are statistically significant and display the expected signs that favor the vertical model in which the cost reducing motive determines FDI over the pure horizontal and knowledge capital models. In particular, differences in human and physical capital per worker are significant at the 5\% and $1 \%$ levels.

The positive signs of the estimated parameters on both measures of differences in relative factor endowments suggest that inward FDI larger differences in human and physical capital per worker between Poland and source countries translate into a higher inward FDI stock. This result confirms the vertical FDI motive. In addition, the positive sign of the coefficient on the GDP-SUM variable, which is significant at the 10\% level, suggests that FDI increases with the combined economic size of both Poland and source countries.

The robustness of the fixed effects estimates is studied using the random effects estimator. The random effects estimates obtained without controlling for individual time effects are presented in column (2) of Table 1. These results differ from the 
Table 1 Full sample estimates for the period 1996-2015

\begin{tabular}{|c|c|c|c|c|}
\hline Explanatory variable & (1) & (2) & (3) & (4) \\
\hline H-DIFF & $\begin{array}{l}0.651 * * \\
(2.14)\end{array}$ & $\begin{array}{l}0.250 \\
(1.11)\end{array}$ & $\begin{array}{l}0.707 * * \\
(2.29)\end{array}$ & $\begin{array}{l}0.304 \\
(1.13)\end{array}$ \\
\hline K-DIFF & $\begin{array}{l}0.768 * * * \\
(3.12)\end{array}$ & $\begin{array}{l}1.285^{* * * *} \\
(6.21)\end{array}$ & $\begin{array}{l}0.652 * * \\
(2.56)\end{array}$ & $\begin{array}{l}1.223 * * * \\
(5.70)\end{array}$ \\
\hline GDP-DIFF & $\begin{array}{l}0.304 \\
(0.82)\end{array}$ & $\begin{array}{l}-0.258 \\
(1.03)\end{array}$ & $\begin{array}{l}0.418 \\
(1.10)\end{array}$ & $\begin{array}{l}-0.260 \\
(1.04)\end{array}$ \\
\hline GDP-SUM & $\begin{array}{l}2.998 * \\
(1.92)\end{array}$ & $\begin{array}{l}3.246^{* * * *} \\
(4.13)\end{array}$ & $\begin{array}{l}0.212 * * * \\
(2.90)\end{array}$ & $\begin{array}{l}3.199 * * * \\
(3.85)\end{array}$ \\
\hline DISTANCE & - & $\begin{array}{l}-2.226 * * * \\
(5.36)\end{array}$ & - & $\begin{array}{l}-2.244 * * * \\
(5.37)\end{array}$ \\
\hline INVESTCOST & $\begin{array}{l}-0.076^{* * * *} \\
(2.59)\end{array}$ & $\begin{array}{l}-0.075^{* * * *} \\
(2.62)\end{array}$ & $\begin{array}{l}-0.093 \\
(0.03)\end{array}$ & $\begin{array}{l}0.498 \\
(0.17)\end{array}$ \\
\hline TRADECOST-source & $\begin{array}{l}0.006 \\
(0.16)\end{array}$ & $\begin{array}{l}-0.002 \\
(0.006)\end{array}$ & $\begin{array}{l}-0.013 \\
(0.31)\end{array}$ & $\begin{array}{l}-0.016 \\
(0.41)\end{array}$ \\
\hline TRADECOST-PL & $\begin{array}{l}0.030 \\
(1.32)\end{array}$ & $\begin{array}{l}0.034^{*} \\
(1.81)\end{array}$ & $\begin{array}{l}-0.478 \\
(0.03)\end{array}$ & $\begin{array}{l}-4.645 \\
(0.24)\end{array}$ \\
\hline CORRUPTION & $\begin{array}{l}0.057 \\
(1.22)\end{array}$ & $\begin{array}{l}0.056 \\
(1.19)\end{array}$ & $\begin{array}{l}0.577 \\
(0.18)\end{array}$ & $\begin{array}{l}1.327 \\
(0.41)\end{array}$ \\
\hline Constant & $\begin{array}{l}-55.587 * * * \\
(3.63)\end{array}$ & $\begin{array}{l}-33.511 * * * \\
(4.60)\end{array}$ & $\begin{array}{l}-7.875 \\
(0.01)\end{array}$ & $\begin{array}{l}247.207 \\
(0.20)\end{array}$ \\
\hline Time-specific effects & No & No & Yes & Yes \\
\hline Country-specific effects & Fixed & Random & Fixed & Random \\
\hline Overall $\mathrm{R}^{2}$ & 0.173 & 0.494 & 0.188 & 0.493 \\
\hline Within $\mathrm{R}^{2}$ & 0.171 & 0.162 & 0.186 & 0.176 \\
\hline Between $\mathrm{R}^{2}$ & 0.184 & 0.702 & 0.180 & 0.693 \\
\hline $\begin{array}{l}\text { F test for country specific effects } \\
\text { (p-val) }\end{array}$ & $\begin{array}{l}15.75 \\
(0.000)\end{array}$ & & $\begin{array}{l}15.72 \\
(0.000)\end{array}$ & \\
\hline $\begin{array}{l}\text { LM test for country specific effects } \\
\text { (p-val) }\end{array}$ & & $\begin{array}{l}393.42 \\
(0.000)\end{array}$ & & $\begin{array}{l}398.73 \\
(0.000)\end{array}$ \\
\hline $\begin{array}{l}\text { Hausman test } \\
\text { (p-val) }\end{array}$ & & $\begin{array}{l}22.89 \\
(0.003)\end{array}$ & & $\begin{array}{l}26.27 \\
(0.157)\end{array}$ \\
\hline
\end{tabular}

$\mathrm{N}=680$ in all specifications; *Significant at the $10 \%$ level of significance, **Significant at the $5 \%$ level of significance, $* * *$ Significant at the $1 \%$ level of significance, $\mathrm{z}$-statistics in parentheses

results reported in column (1) as now the estimated parameter on the difference in relative human capital endowment is not statistically significant at any of the usually accepted levels of statistical significance. Nevertheless, the parameter on the physical capital per worker difference remains significant at the $1 \%$ level and shows the expected positive sign.

In addition, the estimated parameter on the distance variable is statistically significant at the $1 \%$ level and displays a negative sign which is also in line with the vertical reason. The estimated parameter on the combined economic country size becomes now significant at the $1 \%$ level and shows the expected positive sign meaning that FDI increases with the size of the combined GDP in Poland and source 
Table 2 Limited sample estimates for the pre-accession period 1996-2004

\begin{tabular}{|c|c|c|c|c|}
\hline Explanatory variable & (1) & (2) & (3) & (4) \\
\hline H-DIFF & $\begin{array}{l}0.814 \\
(0.81)\end{array}$ & $\begin{array}{l}-0.075 \\
(0.10)\end{array}$ & $\begin{array}{l}0.856 \\
(0.84)\end{array}$ & $\begin{array}{l}-0.083 \\
(0.12)\end{array}$ \\
\hline K-DIFF & $\begin{array}{l}-0.144 \\
(0.40)\end{array}$ & $\begin{array}{l}0.576^{*} \\
(1.89)\end{array}$ & $\begin{array}{l}-0.150 \\
(0.41)\end{array}$ & $\begin{array}{l}0.587 * \\
(1.91)\end{array}$ \\
\hline GDP-DIFF & $\begin{array}{l}-1.377 \\
(1.18)\end{array}$ & $\begin{array}{l}-1.187 * * \\
(2.21)\end{array}$ & $\begin{array}{l}-1.194 \\
(0.99)\end{array}$ & $\begin{array}{l}-1.185^{* * *} \\
(2.20)\end{array}$ \\
\hline GDP-SUM & $\begin{array}{l}5.334 \\
(1.01)\end{array}$ & $\begin{array}{l}5.592 * * * \\
(3.54)\end{array}$ & $\begin{array}{l}0.653 \\
(0.07)\end{array}$ & $\begin{array}{l}5.506^{* * * *} \\
(3.44)\end{array}$ \\
\hline DISTANCE & - & $\begin{array}{l}-1.915^{* * * *} \\
(2.65)\end{array}$ & - & $\begin{array}{l}-1.895^{* *} \\
(2.20)\end{array}$ \\
\hline INVESTCOST & $\begin{array}{l}-0.055 \\
(1.63)\end{array}$ & $\begin{array}{l}-0.049 * \\
(1.64)\end{array}$ & $\begin{array}{l}-0.101 \\
(0.35)\end{array}$ & $\begin{array}{l}-0.047 \\
(1.49)\end{array}$ \\
\hline TRADECOST-source & $\begin{array}{l}0.003 \\
(0.05)\end{array}$ & $\begin{array}{l}0.011 \\
(0.22)\end{array}$ & $\begin{array}{l}0.005 \\
(0.10)\end{array}$ & $\begin{array}{l}0.010 \\
(0.21)\end{array}$ \\
\hline TRADECOST-PL & $\begin{array}{l}-0.001 \\
(0.03)\end{array}$ & $\begin{array}{l}0.002 \\
(0.09)\end{array}$ & $\begin{array}{l}0.096 \\
(0.14)\end{array}$ & $\begin{array}{l}-0.078^{*} \\
(1.72)\end{array}$ \\
\hline CORRUPTION & $\begin{array}{l}0.032 \\
(0.75)\end{array}$ & $\begin{array}{l}0.039 \\
(0.93)\end{array}$ & $\begin{array}{l}0.042 \\
(0.72)\end{array}$ & $\begin{array}{l}-0.376^{* *} \\
(2.13)\end{array}$ \\
\hline Constant & $\begin{array}{l}-30.973 \\
(0.52)\end{array}$ & $\begin{array}{l}-36.132 * * \\
(2.42)\end{array}$ & $\begin{array}{l}24.178 \\
(0.22)\end{array}$ & $\begin{array}{l}0.000 \\
(0.00)\end{array}$ \\
\hline Time-specific effects & No & No & Yes & Yes \\
\hline Country-specific effects & Fixed & Random & Fixed & Random \\
\hline Overall $\mathrm{R}^{2}$ & 0.074 & 0.360 & 0.006 & 0.363 \\
\hline Within $\mathrm{R}^{2}$ & 0.043 & 0.029 & 0.046 & 0.030 \\
\hline Between $\mathrm{R}^{2}$ & 0.074 & 0.436 & 0.016 & 0.440 \\
\hline $\begin{array}{l}\text { F test for country specific effects } \\
\text { (p-val) }\end{array}$ & $\begin{array}{l}19.50 \\
(0.000)\end{array}$ & & $\begin{array}{l}19.19 \\
(0.000)\end{array}$ & \\
\hline $\begin{array}{l}\text { LM test for country specific effects } \\
\text { (p-val) }\end{array}$ & & $\begin{array}{l}429.46 \\
(0.000)\end{array}$ & & $\begin{array}{l}429.43 \\
(0.000)\end{array}$ \\
\hline $\begin{array}{l}\text { Hausman test } \\
\text { (p-val) }\end{array}$ & & $\begin{array}{l}25.90 \\
(0.044)\end{array}$ & & $\begin{array}{l}12.51 \\
(0.406)\end{array}$ \\
\hline
\end{tabular}

$\mathrm{N}=306$ in all specifications; *Significant at the $10 \%$ level of significance, **Significant at the $5 \%$ level of significance, $* * *$ Significant at the $1 \%$ level of significance, $\mathrm{z}$-statistics in parentheses

countries. However, the Hausman test with $p$ value equal 0.003 favors the fixed effects estimator as the proper estimation format.

In columns (3) and (4), we study the robustness of our previous fixed and random effects estimates, respectively, by controlling for individual time specific effects by including dummy variables for particular years of our sample. The estimation results obtained via the fixed effects estimator with controlling for individual time effects, presented in column (3), show that the estimated parameters on both measures of differences in relative factor endowments are statistically significant at the $5 \%$ level and display the positive signs while the difference in the relative country size remains statistically not significant. The estimated parameter on the combined 
Table 3 Limited sample estimates for the post-accession period 2004-2015

\begin{tabular}{|c|c|c|c|c|}
\hline Explanatory variable & (1) & (2) & (3) & (4) \\
\hline H-DIFF & $\begin{array}{l}0.224 \\
(0.60)\end{array}$ & $\begin{array}{l}-0.077 \\
(0.28)\end{array}$ & $\begin{array}{l}0.226 \\
(0.60)\end{array}$ & $\begin{array}{l}-0.087 \\
(0.32)\end{array}$ \\
\hline K-DIFF & $\begin{array}{l}-0.034 \\
(0.08)\end{array}$ & $\begin{array}{l}1.458 * * * \\
(4.99)\end{array}$ & $\begin{array}{l}0.040 \\
(0.08)\end{array}$ & $\begin{array}{l}1.505^{* * * *} \\
(5.12)\end{array}$ \\
\hline GDP-DIFF & $\begin{array}{l}0.262 \\
(0.65)\end{array}$ & $\begin{array}{l}-0.247 \\
(1.09)\end{array}$ & $\begin{array}{l}0.240 \\
(0.58)\end{array}$ & $\begin{array}{l}-0.259 \\
(1.15)\end{array}$ \\
\hline GDP-SUM & $\begin{array}{l}-0.968 \\
(0.30)\end{array}$ & $\begin{array}{l}3.372 * * * \\
(4.66)\end{array}$ & $\begin{array}{l}-1.222 \\
(0.32)\end{array}$ & $\begin{array}{l}3.421 \text { *** } \\
(4.72)\end{array}$ \\
\hline DISTANCE & - & $\begin{array}{l}-2.651 * * * \\
(7.31)\end{array}$ & - & $\begin{array}{l}-2.625 * * * \\
(7.23)\end{array}$ \\
\hline INVESTCOST & $\begin{array}{l}-0.109 \\
(1.23)\end{array}$ & $\begin{array}{l}-0.199 * * * \\
(3.02)\end{array}$ & $\begin{array}{l}-0.103 \\
(0.04)\end{array}$ & $\begin{array}{l}0.840 \\
(0.31)\end{array}$ \\
\hline TRADECOST-source & $\begin{array}{l}0.043 \\
(0.61)\end{array}$ & $\begin{array}{l}0.003 \\
(0.05)\end{array}$ & $\begin{array}{l}0.054 \\
(0.70)\end{array}$ & $\begin{array}{l}0.017 \\
(0.25)\end{array}$ \\
\hline TRADECOST-PL & $\begin{array}{l}-0.006 \\
(0.06)\end{array}$ & $\begin{array}{l}-0.061 \\
(0.66)\end{array}$ & $\begin{array}{l}-0.309 \\
(0.02)\end{array}$ & $\begin{array}{l}-7.036 \\
(0.40)\end{array}$ \\
\hline CORRUPTION & $\begin{array}{l}0.307 * \\
(1.79)\end{array}$ & $\begin{array}{l}0.329 * \\
(1.93)\end{array}$ & $\begin{array}{l}0.497 \\
(0.17)\end{array}$ & $\begin{array}{l}1.744 \\
(0.59)\end{array}$ \\
\hline Constant & $\begin{array}{l}-4.686 \\
(0.12)\end{array}$ & $\begin{array}{l}-38.888 * * * \\
(4.70)\end{array}$ & $\begin{array}{l}10.126 \\
(0.01)\end{array}$ & $\begin{array}{l}395.740 \\
(0.35)\end{array}$ \\
\hline Time-specific effects & No & No & Yes & Yes \\
\hline Country-specific effects & Fixed & Random & Fixed & Random \\
\hline Overall $\mathrm{R}^{2}$ & 0.011 & 0.566 & 0.003 & 0.572 \\
\hline Within $\mathrm{R}^{2}$ & 0.063 & 0.037 & 0.072 & 0.047 \\
\hline Between $\mathrm{R}^{2}$ & 0.033 & 0.808 & 0.015 & 0.811 \\
\hline $\begin{array}{l}\text { F test for country specific effects } \\
\text { (p-val) }\end{array}$ & $\begin{array}{l}25.90 \\
(0.000)\end{array}$ & & $\begin{array}{l}11.01 \\
(0.000)\end{array}$ & \\
\hline $\begin{array}{l}\text { LM test for country specific effects } \\
\text { (p-val) }\end{array}$ & & $\begin{array}{l}72.13 \\
(0.000)\end{array}$ & & $\begin{array}{l}74.34 \\
(0.000)\end{array}$ \\
\hline $\begin{array}{l}\text { Hausman test } \\
\text { (p-val) }\end{array}$ & & $\begin{array}{l}28.22 \\
(0.000)\end{array}$ & & $\begin{array}{l}26.00 \\
(0.054)\end{array}$ \\
\hline
\end{tabular}

$\mathrm{N}=408$ in all specifications; *Significant at the $10 \%$ level of significance, **Significant at the $5 \%$ level of significance, $* * *$ Significant at the $1 \%$ level of significance, $\mathrm{z}$-statistics in parentheses

economic country size displays a positive sign and is statistically significant at the $1 \%$ level. Hence, these results support the vertical FDI model.

Finally, the estimation results obtained via the random effects estimator with controlling for individual time effects are presented in column (4). These results are similar to the results reported in column (2) and show that the only measure of differences in factor proportions that is significant at the $1 \%$ level is the difference in capital per worker. Moreover, the estimated parameter on the distance variable remains statistically significant at the $1 \%$ level. In addition, the estimated parameter on the combined economic country size is also significant at the $1 \%$ level. The remaining explanatory variables are not significant at all. Hence, these results also 
support the vertical model of FDI. The Hausman test with p-value equal 0.157 favors the random effects estimator as the proper estimation format.

In Tables 2 and 3, we report the results obtained for the subsamples limited to the pre-accession period 1996-2004 and the post-accession period 2004-2015. The particular columns in Tables 2 and 3 are the counterparts of columns in Table 1. In column (1) of Table 2, we show the results obtained for the pre-accession period using the fixed effects estimator without controlling for individual time effects. These results show that none of the explanatory variables is statistically significant.

In column (2) of Table 2, we show the estimation results obtained for the preaccession period using the random effects estimator without controlling for individual time effects. This time the estimated parameter on the physical capital per worker differences variable is significant only at the $10 \%$ level and shows the expected positive sign. The estimated parameter on the geographic distance variable is significant already at the $1 \%$ level and shows an expected negative sign.

However, in contrast to the estimation results obtained for the full sample this time also the coefficient on the difference in the economic country size is significant at the 5\% level and negative which supports the horizontal FDI motive. This means that increased differences in market sizes between Poland and its investment partners decrease the inward FDI stock. Finally, the estimated parameter on the combined GDP is positive and statistically significant at the $1 \%$ level. The Hausman test with p-value equal 0.044 favors the fixed effects estimator as the proper estimation format.

The estimation results obtained via the fixed effects estimator with controlling for individual time effects are presented in column (3) of Table 2. These results show that in qualitative terms the inclusion of time effects does not change our previous conclusions, obtained on the basis of the estimates reported in column (1) as none of the explanatory variables are statistically significant.

Finally, column (4) of Table 2 shows the estimation results obtained via the random effects estimator with controlling for individual time effects. These results show that, similar to the estimates reported in column (2), the differences in capital to labor ratios, the differences in the economic size, geographical distance and the GDP sum, are significant and show the expected signs. Moreover, the estimated parameter on the difference in capital to labor ratios variable is statistically significant only at the $10 \%$ level. The Hausman test with p-value equal 0.406 clearly favors the random effects estimator as the proper estimation format.

Therefore, the results obtained for the subsample consisting of the pre-accession years 1996-2004 are different from the results obtained for the full sample as in this period the horizontal motive for FDI was also important. These results suggest that in the pre-accession period both horizontal and vertical reasons for FDI were important which supports the knowledge capital model.

Finally, in Table 3 we report the results obtained for the subsample containing the post-accession years 2004-2015. In column (1) of Table 3, we report the estimation results obtained for the post-accession period using the fixed effects estimator without controlling for individual time effects. These results show that the only statistically significant explanatory variable is the measure of corruption which is significant only at the $10 \%$ level. 
In column (2) of Table 3, we report the results obtained for the post-accession period using the random effects estimator without controlling for individual time effects. These results are very similar to the results obtained for the full sample as the variables that are statistically significant at the $1 \%$ level include the differences in capital to labor ratios, the GDP sum, geographical distance, and the investment cost while the measure of corruption is significant at the $10 \%$ level only. The estimated coefficient on the difference in the economic size variable is not significant at all which means that in the post-accession period only the vertical FDI motive remains important. However, the Hausman test with p-value equal 0.000 favors the use of the fixed effects estimator.

The estimation results obtained via the fixed effects estimator with controlling for individual time effects are shown in column (3) of Table 3. Compared to the results reported in column (1), the measure of corruption loses its previous statistical significance and the remaining variables are not statistically significant at all.

Finally, in column (4) of Table 3 we report the results obtained via the random effects estimator with controlling for individual time effects. These results are similar to the results reported in column (2) as the significant variables at the $1 \%$ level include the differences in capital to labor ratios, geographical distance and the GDP sum, which display the expected signs. However, after controlling for time specific effects, the investment cost and the measure of corruption lose their previous statistical significance. Similarly, the estimated parameter on the difference in the economic size variable remains not significant. The Hausman test with p-value equal 0.054 favors the random effects estimator as the proper estimation format. Hence, the estimates obtained for the sub-sample consisting of the post-accession years show that the knowledge capital model does not contribute to the better understanding of inward FDI determinants in Poland compared to the pure vertical model.

\section{Conclusions}

In this study, we used standard panel data analysis to empirically investigate various reasons for inward FDI originating from the OECD member states in Poland during the period 1996-2015. The model's estimated empirical specification was derived from the modified knowledge-capital model of multinational enterprise that included two types of capital: human and physical. Our empirical evidence for the full sample period pointed to efficiency seeking rather than market seeking as the main reason for FDI in Poland which favored the pure vertically-integrated model of multinational enterprise over the knowledge capital model and the pure horizontal model.

However, when the model was re-estimated for the pre-accession period only, both efficiency seeking and market seeking motives were important. This result was in line with the predictions of the modified knowledge capital model of multinational enterprise. Finally, the estimation results obtained for the post-accession years only revealed that the pure vertical model was preferred to both the pure horizontal model and the knowledge capital model. Moreover, it was found that the magnitude of the estimated coefficient on the differences in physical capital per worker between 
Poland and the source countries was visibly higher after its accession to the EU. This means that the importance of the vertical reason for inward FDI in Poland has increased over time. This suggests the changing pattern of inward FDI in Poland due to its increased involvement into the Global Value Chains (GVCs) organized by the MNEs from the source countries. This result is in line with the general pattern of MNE activity in Poland reported in Cieślik (2019b).

Our empirical results have several important policy implications. In particular, the increased importance of vertical FDI and participation in GVCs following the EU accession have important implications for both labor market and competition policies in the host country. On one hand, vertically-integrated MNEs create demand for labor and intermediate inputs that may in turn translate into rising wages and stimulate further host country economic development. On the other hand, vertical FDI is usually not associated with increased competition with indigenous firms in product markets in the host country and the fear that these firms would be driven out of the market by more productive MNEs. In contrast, indigenous firms supplying parts and components can cooperate with MNEs within the GVCs and, at the same time, improve their productivity benefiting from a wide range of positive spillovers resulting from various interactions with them.

Therefore, in future studies it would be useful to devote more attention to the role of MNEs in GVCs in Poland and other post-transition countries in Central and Eastern Europe. Moreover, it would be recommended to extend the sample and include also other source countries in addition to the OECD members. In addition, in future work it would be desirable to perform a sectoral level analysis using disaggregated FDI data to validate whether the reasons for inward FDI differ across particular sectors of the Polish economy. The special attention should be devoted to high value added and technologically advanced sectors that are essential for building host country's innovation potential and stimulating its economic development.

Open Access This article is distributed under the terms of the Creative Commons Attribution 4.0 International License (http://creativecommons.org/licenses/by/4.0/), which permits unrestricted use, distribution, and reproduction in any medium, provided you give appropriate credit to the original author(s) and the source, provide a link to the Creative Commons license, and indicate if changes were made.

\section{Appendix}

See Tables 4, 5. 


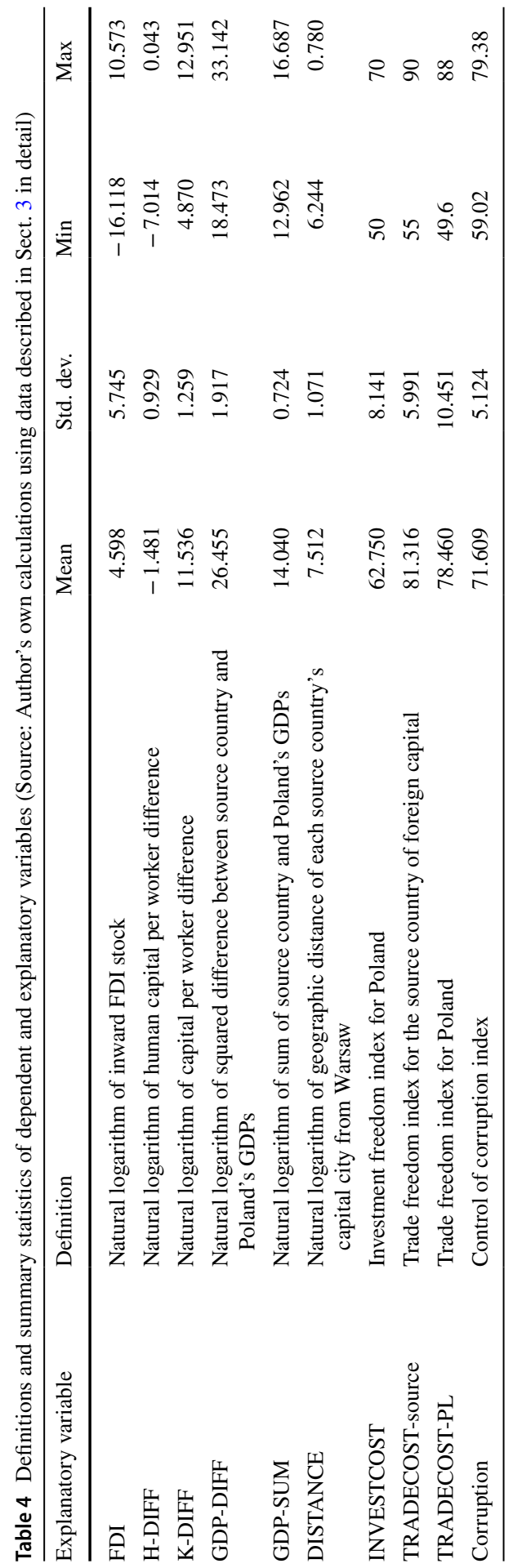




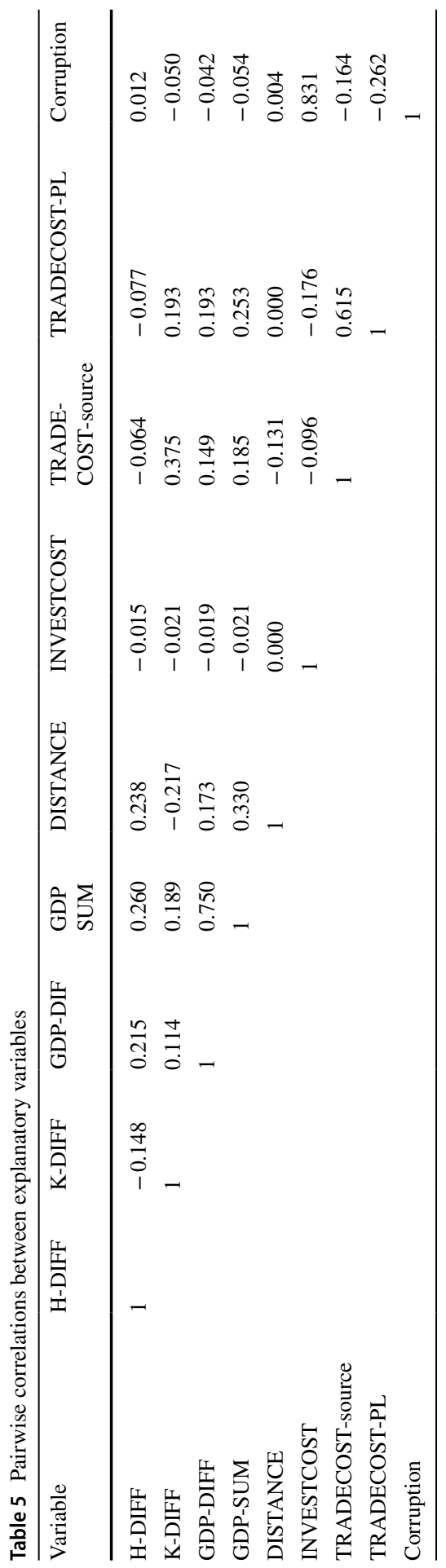




\section{References}

Baniak, A., Cukrowski, J., \& Herczyński, J. (2005). On the determinants of foreign direct investment in transition economies. Problems of Economic Transition, 48(2), 6-28.

Benacek, V., Gronicki, M., Holland, D., \& Sass, M. (2000). The determinants and impact of foreign direct investment in Central and Eastern Europe: A comparison of survey and econometric evidence. Transnational Corporations, 9(3), 163-212.

Bergstrand, J. H., \& Egger, P. (2007). A knowledge and physical capital model of international trade flows, foreign direct investment and multinational enterprises. Journal of International Economics, 73(2), 278-308.

Bergstrand, J. H., \& Egger, P. (2013). Shouldn't physical capital also matter for multinational enterprise activity? Review of International Economics, 21(5), 945-965.

Bevan, A. A., \& Estrin, S. (2004). The determinants of foreign direct investment into European transition economies. Journal of Comparative Economics, 32(4), 775-787.

Braconier, H., Norback, H. P. J., \& Urban, D. (2005). Reconciling the evidence on the knowledge-capital model. Review of International Economics, 13(4), 770-786.

Brainard, L.S. (1993a). A simple theory of multinational corporations and trade with a tradeoff between proximity and concentration, NBER Working Paper 4269.

Brainard, L.S. (1993b). An empirical assessment of the factor proportions explanation of multinational sales, NBER Working Paper 4580.

Brainard, L. S. (1997). An empirical assessment of the proximity concentration tradeoff between multinational sales and trade. American Economic Review, 87(4), 520-544.

Brenton, P., Di Mauro, F., \& Lucke, M. (1999). Economic integration and FDI: An empirical analysis of foreign investment in the EU and in Central and Eastern Europe. Empirica, 26(2), 95-121.

Carr, D. L., Markusen, J. R., \& Maskus, K. E. (2001). Estimating the knowledge capital model of the multinational enterprise. American Economic Review, 91(3), 693-708.

Carstensen, K., \& Toubal, F. (2004). Foreign direct investment in Central and Eastern European countries: A dynamic panel analysis. Journal of Comparative Economics, 32(1), 3-22.

Chen, Y., Horstmann, I. J., \& Markusen, J. R. (2012). Physical capital, knowledge capital, and the choice between FDI and outsourcing. Canadian Journal of Economics, 45(1), 1-15.

Cieślik, A. (2013). Horizontally integrated MNE and plant heterogeneity. Bank i Kredyt, 44(6), 605-622.

Cieślik, A. (2015a). North-North FDI, exporting and the first mover advantage. Bank $i$ Kredyt, 46(2), $109-128$.

Cieślik, A. (2015b). Imperfect competition, productivity differences and proximity-concentration tradeoffs. Ekonomia, 40, 7-30.

Cieślik, A. (2016). Exports versus FDI in Smith-Motta framework. Equilibrium Quarterly Journal of Economics and Economic Policy, 11(2), 189-218.

Cieślik, A. (2017). Determinants of MNE activity in Poland: The case of firms from EU-15. Entrepreneurial Business and Economics Review, 5(1), 151-167.

Cieślik, A. (2018). Leader-follower model of reciprocal FDI and international trade. Argumenta Oeconomica, 41(2), 91-112.

Cieślik, A. (2019a). What attracts multinational enterprises from the new EU member states to Poland? Eurasian Business Review. https://doi.org/10.1007/s40821-019-00122-z.

Cieślik, A. (2019b). MNE activity in poland: Horizontal, vertical or both? Emerging Markets Finance and Trade. https://doi.org/10.1080/1540496X.2018.1549029.

Cieślik, A., \& Goczek, Ł. (2018). Control of corruption, international investment, and economic growth Evidence from panel data. World Development, 103, 323-335.

Cieślik, A., \& Ryan, M. (2004). Explaining Japanese direct investment flows into an enlarged Europe: A comparison of gravity and economic potential approaches. Journal of the Japanese and International Economies, 18(1), 12-37.

Cieślik, A., \& Ryan, M. (2012). Productivity differences and foreign market entry in an oligopolistic industry. Open Economies Review, 23(3), 531-557.

Collie, D. R. (2011). Multilateral trade liberalization, foreign direct investment and the volume of world trade. Economics Letters, 113(1), 47-49.

Davies, R. B. (2008). Hunting high and low for vertical FDI. Review of International Economics, 16(2), 250-267. 
Garibaldi, P., Mora, N., Sahay, R., \& Zettelmeyer, J. (2001). What moves capital to transition economies? IMF Staff Papers, 48, 109-145.

Gorbunova, Y., Infante, D., \& Smirnova, J. (2012). New evidence on FDI determinants: An appraisal over the transition period. Prague Economic Papers, 2, 129-149.

Helpman, E. (1984). A simple theory of trade with multinational corporations. Journal of Political Economy, 92(3), 451-471.

Helpman, E., \& Krugman, P. (1985). Market structure and foreign trade: Increasing returns, imperfect competition and the international economy. Cambridge: MIT Press.

Helpman, E., Melitz, M. J., \& Yeaple, S. R. (2004). Export versus FDI with heterogeneous firms. American Economic Review, 94(1), 300-316.

Horstmann, I., \& Markusen, J. R. (1987). Strategic investments and the development of multinationals. International Economic Review, 28(1), 109-121.

Krugman, P. (1983). The 'new theories' of international trade and multinational enterprise. In D. B. Audretsch \& Ch P Kindleberger (Eds.), The Multinational Corporation in the 1980s. Cambridge: MIT Press.

Lansbury, M., Pain, N., \& Smidkova, K. (1996). Foreign direct investments in Central Europe since 1990: An econometric study. National Institute Economic Review, 156, 104-113.

Markusen, J. R. (1984). Multinationals, multi-plant economies and the gains from trade. Journal of International Economics, 16(3-4), 205-226.

Markusen, J. R. (2002). Multinational firms and the theory of international trade. Cambridge: MIT Press.

Markusen, J. R. (2013). Multinational firms. In D. Bernhofen, R. Falvey, D. Greenaway, \& U. Kreickemeier (Eds.), Palgrave Handbook of International Trade. Basingstoke: Palgrave Macmillan.

Markusen, J. R., \& Stähler, F. (2011). Endogenous market structure and foreign market entry. Review of World Economics, 147(2), 195-215.

Markusen, J. R., \& Strand, B. (2009). Adapting the knowledge-capital model of the multinational enterprise to trade and investment in business services. World Economy, 32(1), 6-29.

Markusen, J. R., \& Venables, A. J. (1998). Multinational firms and the new trade theory. Journal of International Economics, 46(2), 183-203.

Markusen, J. R., \& Venables, A. J. (2000). The theory of endowment, intra-industry and multinational trade. Journal of International Economics, 52(2), 209-234.

National Bank of Poland (NBP). (2003-2018). Foreign direct investment in Poland.

Sinha, U. B. (2010). Strategic licensing, exports, FDI, and host country welfare. Oxford Economic Papers, 62(1), 114-131.

Torrisi, C. R., Delaunay, C. J., Kocia, A., \& Lubieniecka, M. (2009). FDI in Poland: Determinants and implications for countries in transition. Ekonomia, 23, 3-15.

Wach, K., \& Wojciechowski, L. (2016). Determinants of inward FDI into Visegrad countries: Empirical evidence based on panel data for the years 2000-2012. Economics and Business Review, 2(1), 34-52.

Zhang, K. H., \& Markusen, J. R. (1999). Vertical multinationals and host-country characteristics. Journal of Development Economics, 59(2), 233-252.

Publisher's Note Springer Nature remains neutral with regard to jurisdictional claims in published maps and institutional affiliations. 